\title{
METHODOLOGICAL ASPECTS OF THE DEVELOPMENT OF TECHNOLOGICAL ENTREPRENEURSHIP AND IMPLEMENTATION OF FINANCIAL SUPPORT TOOLS IN RUSSIAN UNIVERSITIES
}

Irina Babkina, Anna Bokova, Maria Bulygina, Dmitry Sukhanov, Maxim Syryamkin, Michail Chikov

National Research Tomsk State University, 634050, 36 Lenin Avenue, Tomsk, Russia

\begin{abstract}
This article describes the development of methods of identification and support of communication between a developer and a technological entrepreneur. It is to promote university research activities. Special attention is paid to stimulating inventive activity and a university need in evolution of a developer from an inventor to series developmental engineer. The importance of an entrepreneurial path has been empathized. Financial tools of attraction of alternative funding for university innovative projects (e.g. endowment fund) have been analyzed.
\end{abstract}

\section{Introduction}

Today the world's leading universities focus on an effective system involving the integration of scientific, technical and production areas in the process of socio-economic development of society. Universities are no longer just a place of concentration of scientific research and fundamental knowledge. They play the role of the most important entities that determine the pace of development, structure and processes of formation of an innovative field. The main difficulties of creating integration relations include poor material and technical base of universities, source of funding of innovative activity [1-3].

\section{Some aspects of the development of technological entrepreneurship in Russian universities}

The key factor of innovative entrepreneurship - is technology transfer. Reorganization of universities is only possible through the implementation of the technology transfer mechanism, which is necessary to motivate inventor to invent, and an entrepreneur to run a business. Thus, it is necessary to identify principles of the formation of innovative environment.

\footnotetext{
Corresponding author: maximus70sir@gmail.ru
} 
Firstly, the principle of equal opportunities - equal access to research, innovative and entrepreneurial activities for students, teachers, researchers and other university personnel. Secondly, the principle of self-organizing project teams - creation of conditions for teams necessary to create and implement projects. Thirdly, the principle of an entrepreneurial path - the absence of any obstacles and limitations for those wishing to combine teaching and / or research activities with an entrepreneurial one within the walls of one university. Young cosmopolitan scientists will be able to implement their ideas, organize their research team, establish collaboration, earn money, which will keep them at the university. This mechanism must be flexible, but stable.

Today Russian universities participating in the project 5-100 (a comprehensive academic excellence initiative that unites top-tier Russian universities) take a pattern by teams of well-known and foreign scientists. Rather than focusing on the faculties, laboratories and departments, the university focuses on the stimulation and motivation of project teams, which must accumulate young cosmopolitan and competent local scientists, and students. Such teams are able organize themselves to carry out projects with the possibility to connect laboratories and departments. They can also be included in international project groups. Such teams mostly focus on commercially attractive projects, which include contract research (applied research) and research and development, market research. Gradually, in order to support and motivate project and business teams and facilitate the exchange of inventive and entrepreneurial knowledge and technologies as well as to create spin-off companies, special tools must be established.

One of the main conditions of the international competitiveness of modern universities is a well-functioning system of financial support of their activities. It includes a steady access to alternative funding sources. This ensures the independence of the university and determines the degree of its adaptability during constant changes.

According to the Statistics of Science and Education [4] the main source of university research and development funding is the federal budget (over 50\%), resources of the business sector are about $25 \%$, the funds of the universities are less than $10 \%$. Financial support of innovation and research activities of universities is provided in the form of grants and subsidies through competitive tools of federal programs and projects.

The Ministry of Science and Education of the Russian Federation implements the project 5-100, which involves funding aimed at selecting at least five universities conforming to level of the top 100 world universities according to the most authoritative world rankings - Quacquarelli Symonds, Times Higher Education or Academic Ranking of World Universities.

The human factor (human capital) is key to success of R\&D. Thus investment in science is, first of all, investment in the human capital of the country [5].

\section{Some features of tools of financial support of innovative projects in the Russian universities}

Funding of innovative activity in Russian universities depends on the type of R\&S and is financially supported from different sources.

Applied research is mainly ordered by enterprises of different sectors of the economy. For universities signing these kind of contracts for R\&D is the most significant and preferable. This type of funding is very important for the development of applied science in general. An example of successful collaboration between enterprises and universities is creation of a scientific and educational center Radio Electronics and Microwave at the Tomsk State University in cooperation with Research \& Production Company Micran. 
There are several industries that are actively supported by the government: space, military, railway, energy. This kind of scientific research is funded by the Advanced Research Foundation, Russian Fundamental Research Fund, Russian Science Foundation, Russian Humanitarian Scientific Fund. Though Russian venture industry is still underdeveloped and venture capital is poorly integrated in the innovative ecosystem of universities, it becomes more affordable for innovative companies. In 2006 OJSC Russian Venture Company (RVC) was established. With the participation of RVC there were formed eight venture capital funds, in which $51 \%$ belong private investors [6].

Many Russian universities are actively developing endowment funds. The existence of such funds does not guarantee quick results. They require a long time, a professional team and fundraising activities effectively integrating education, research and innovation policies of universities. The university must have at least a few endowment funds: educational, research, innovative, and others.

In Russia first endowment funds were established in 2007. Now the program of development of endowment funds in regions is supported by the Vladimir Potanin Charity Fund.

However high potential of such funds as a tool of additional budgeting of universities is not realized. According to open sources, in 2015 the size of the endowment fund of one of the largest universities in the Russian Federation (Moscow State University of Foreign Affairs) amounted more than 1.5 billion rubles. At the same time, the funds of most universities in Russia, have less than 20 million rubles. Such amounts are not enough for effective activity, mainly because universities can use the income received from the endowment capital, not the endowment capital itself. According to experts, in order to be profitable for the university the minimum size of its endowment fund should be at least 100 - 150 million rubles.

European and American researchers are publishing data on the financial stability of endowment funds [7-9], risk prevention [10], and investment policy [11]. In Russian publications devoted to endowment funds special attention is paid to necessary changes in the institutional environment of the Russian economy and education, undeveloped legal framework. Another problem is business is not ready to invest in such funds, because it believes targeted aid to be more efficient.

In order to solve this complex problem the government can provide the following support.

Firstly, the establishment of tax incentives for profit completely or partially to the donors (individuals, legal entities, and specialized management organizations). It should be noted that the law regarding endowment capital allows making donations not only in money assets but also in security papers and real estate. However, endowment funds are not property tax free. Thus donated real estate can become a major article of expenditure instead of the source of income. Thus it is necessary to establish tax incentives for donated real assets (at least for a certain period of time, or until it reaches a certain amount of money, for example, 20 million rubles).

Second, the costs associated with the formation and replenishment of endowment capital of universities must be reduced. The government can assist in reducing of banking commission in case of transferring substantial sums of money, at least for banks with state participation.

Third problem in the functioning of endowment funds in Russia is that the endowment capital of universities are increased by donations of successful businessmen and politicians. But this resource is often not available for universities, located in the regions. Such universities have no access to the head offices and management of donating corporations. They are mostly based in Moscow, and in most cases, cooperate with Moscow universities. 
Finally, activities aimed at supporting universities by alumni are not common. In general, philanthropy in universities is not very popular. In Russia charity, is mainly aimed at helping sick children. Thus, it is important to develop a strategy for the development of academic fundraising [12] with the support of university leaders and government officials $[13,14]$.

In Tomsk State University an endowment fund assisting projects in education, science and culture was established in 2010 . The fund provides scholarship programs and necessary help in publishing activities. Also the programs of support of the Siberian Botanical Garden and Creation of Educational Systems in the Field of Culture and Art in TSU are being implemented. A group developing fundraising strategy has been created. It is responsible for special events (including different marketing and communication activities) aimed at raising funds from different categories of donors. Special attention is paid at work with TSU alumni. The main directions of TSU fundraising are collaboration with majors donors (alumni, philanthropists, entrepreneurs) and the development of public fund-raising.

\section{Conclusion}

Any separate invention acquires its value only because of its possible development in a long process chain of the innovation process: from an idea, to manufacturing. Many players are involved in this process. The major player in the process is a technological entrepreneur. Even though in the Russian reality, he is not considered to be really important.

Entrepreneurial path does not exist in the Russian university as a matter of discussion. Jobs in spin-off companies, or in application-oriented projects ordered by an enterprise are not appreciated in the academic community. University teachers do not support and encourage students successful in entrepreneurial activities whose academic achievements are not very high. Entrepreneurial indicators not taken in the laboratory, department, faculty, university KPI. There are no special academic programs for identification of entrepreneurial skills and abilities.

There are no financial tools for attracting alternative funding of innovative projects in universities (e.g. endowment funds). Economic stability and independence of R\&D centers are impossible without collaboration with technological entrepreneurs, who can help engineers to commercialize as many inventions as possible in an industrial turnover. They involve relevant businessmen and companies in the task setting process. They also assist in sharing production costs between interested parties, making the technology financially accessible.

\section{Acknowledgment}

The paper was written as part of the research project No. 8.2.31.2015, carried out with the support of the Program "Research Foundation of Tomsk State University named after D.I.Mendeleev" in 2015 - 2016, grant RFBR No. 16-29-12858.

\section{References}

[1] I. A. MacLeod, Engineering, construction and architectural management 17, 21 (2010) doi: 10.1108/09699981011011294

[2] M. Almeida, International journal of technology management \& sustainable development 7, 39(2008) doi: 10.1386/ijtm.7.1.39_1 
[3] P. Jones, R. Patz, B. Thomas, S. McCarthy, Industry and Higher Education 28, 39 (2014)

[4] Science and Education Statistics (6), URL: http://www.csrs.ru/archive/stat_2015_finance/finance_2015.pdf

[5] A. Vyzhigin, SHS Web Conf. 29, 02045 (2016) doi:10.1051/shsconf/20162902045

[6] The official website of OJSC «Russian Venture Company» URL: http://www.rusventure.ru/ru/

[7] M. Drouvelisa, J. Sonnemans, The endowment effect in games URL: http://papers.tinbergen.nl/15114.pdf

[8] S. N. Gary, Journal of College and University Law, Forthcoming URL:http://papers.ssrn.com/sol3/papers.cfm?abstract_id=2656640

[9] C. Goodhart, C. Osorio, D. Tsomocos , CESifo Working Paper Series No. 2885, (2009)

[10] S.G. Dimmock, Review of economics and statistics 94, 789 (2012) doi: 10.1162/REST_a_00180

[11] R. C. Merton, Optimal investment strategies for University endowment funds, In Studies of supply and demand in higher education, edited by C. Clotfelter and M. Rothschild (University of Chicago Press, Chicago, 1993)

[12] S. M. Pritchard, Libraries and the Academy 11, 595 (2011) doi: 10.1353/pla.2011.0018

[13] B. L. Ciconte, and J.G. Jacob, Fundraising Basics: A Complete Guide, second edition (MA: Jones and Bartlett Publishers, Sudbury, 2001)

[14] R.R. Kharisova, S.V. Kiselev, N.M. Chikisheva, V.L. Grankina, L.V. Khabibullina, Journal of sustainable development 8, 194 (2015) doi: 10.5539/jsd.v8n3p194 